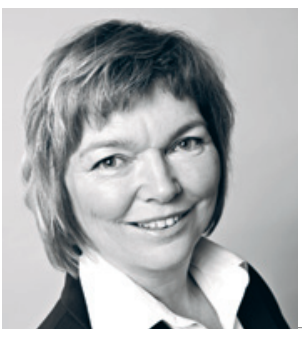

Charlotte Haug (f. 1959) er dr.med. og har en mastergrad i helsetjenesteforskning fra Stanford University. Hun har vært sjefredaktør i Tidsskriftet siden 2002

Foto: Einar Nilsen

\title{
Hva skjedde med Dan Markingson?
}

Tidlig om morgenen 8. mai 2004 mottok Mary Weiss den tyngste beskjeden en mor kan få: Hennes sønn Dan Markingson hadde tatt sitt eget liv. I lengre tid hadde Weiss advart legene som behandlet sønnen om at dette kunne bli utgangen. Mindre enn to uker tidligere hadde hun i desperasjon lagt igjen en melding på legens telefonsvarer (1): «Må vi vente til han dreper seg selv eller noen andre før noen gjør noe?»

Høsten 2003 ble Dan Markingson alvorlig syk, med paranoide og andre vrangforestillinger. Da han 12. november truet med å drepe sin mor hvis han ble «bedt» om å gjøre det, ble Mary Weiss redd og tilkalte politiet. Dan ble innlagt på Fairview University Medical Center i Minnesota og satt på risperidon av legen. Stephen C. Olson mente at Dan var psykotisk og farlig og søkte derfor to dager senere om å få ham tvangsinnlagt i et psykiatrisk sykehus fordi han «ikke var i stand til å fatte beslutninger på egne vegne». 17. november anbefalte også en klinisk psykolog tvangsinnleggelse. I Minnesota kan pasienter som er tvangsinnlagt unngå psykiatrisk sykehus hvis de er villige til å følge behandlingsprogrammet psykiateren anbefaler, et «stay of commitment». Olson ba om et slikt for Dan 20. november, fikk innvilget det og foreslo at Dan skulle bli med i en studie finansiert av legemiddelindustrien. 21. november, uten pårørende til stede, signerte Dan Markingson et skjema der han samtykket i å delta i CAFE-studien (Comparison of Atypicals in First Episode) $(1,2)$. Hvordan var det mulig at Dan, som et par dager tidligere var vurdert som «ikke i stand til å fatte beslutninger på egne vegne», plutselig var kompetent til å samtykke i å delta i en klinisk legemiddelstudie?

Studien virket tilforlatelig $(1,2)$. Hensikten var å sammenlikne effekten av tre «atypiske» antipsykotiske medikamenter - quetiapin, olanzapin og risperidon, alle godkjent av FDA. Studien var finansiert av Astra-Zeneca, produsenten av quetiapin (Seroquel). Det som ikke var så tydelig var at dette var en «non-inferiority study», altså en studie der hensikten ikke var noen annen enn å vise at ingen av medikamentene var dårligere enn de andre. Å påvise en positiv signifikant forskjell mellom ulike behandlingsalternativer er vanskelig. A sette opp et forsøk slik at ingenting blir signifikant forskjellig fra noe annet er enkelt. Hvis man trenger et visst antall pasienter og en definert forskjell mellom gruppene som sammenliknes for å få en statistisk signifikant behandlingseffekt, er det bare å ha små nok grupper for at forskjellen mellom dem ikke skal bli signifikant forskjellig. Det er bare én hensikt med «non-inferiority»-studier: Å gi produsenten av det aktuelle legemidlet ryggdekning for å markedsføre det som like godt som de andre legemidlene i gruppen. Disse kliniske studiene gir ikke deltakende eller fremtidige pasienter noen behandlingsmessig fordel. Får de som deltar klar beskjed om at det er markedsføring, ikke forskning, de er med på?

CAFE-studien var ikke bare uten klare fordeler for Dan Markingson, den innebar også at han utsatte seg for risiko. Blant annet var det ikke anledning til å ta pasientene av det medikamentet de var blitt satt på gjennom den dobbeltblinde prosessen selv om det ikke virket, og det var restriksjoner på hvor mange medikamenter de kunne få for å dempe bivirkninger. Dermed hadde pasientene i CAFE-studien færre behandlingsalternativer enn andre (1).

Da Mary Weiss fant ut at sønnen var rekruttert til å delta i en klinisk studie, forsøkte hun gang på gang å protestere - uten å bli hørt. Hun ringte og skrev til Stephen C. Olson, som ledet studien, og til Charles Schulz, som ledet psykiatrisk avdeling på sykehuset, og fortalte om sin bekymring for sønnens utvikling - ikke minst det hun oppfattet som hans «indre raseri». Schulz svarte at «det er ikke åpenbart for meg hvordan du mener at de som behandler ham skulle kunne håndtere dette». Det var etter dette at Mary Weiss ringte inn telefonbeskjeden.

I årene som er gått etter Dan Markingsons tragiske dødsfall, har en rekke enkeltpersoner, grupper av forskere og organisasjoner forsøkt å få i gang en uavhengig granskning av CAFE-studien. Ikke minst fordi flere av forskerne ble finansiert av legemiddelfirmaene. Alle henvendelser er blitt avvist. I oktober 2013 sendte en gruppe på mer enn 170 forskere innen helsejus, helseetikk og forskning, deriblant tidligere og nåværende redaktører av medisinske tidsskrifter, et brev til universitetet i Minnesota. Der ba de innstendig om en åpen undersøkelse av studien (3). Også denne oppfordringen ble avvist.

Helsinki-deklarasjonen regulerer medisinsk forskning. Siste versjon (4) minner oss om at «while the primary purpose of medical research is to generate new knowledge, this goal can never take precedence over the rights and interests of individual research subjects» og at «medical research involving human subjects may only be conducted if the importance of the objective outweighs the risks and burdens to the research subjects». Hvis man hadde fulgt dette, ville Dan Markingson ikke blitt innrullert i CAFE-studien. Hvor mange andre er blitt utnyttet?

Vi hører ofte at det er mange «byråkratiske» hindringer i veien for medisinsk forskning. At samtykkeerklæringer, interessekonfliktskjemaer, forskningsprotokoller og søknader til etiske komiteer forsinker medisinske fremskritt. Ved utgangen av året er det grunn til å stoppe opp og tenke over om dette er sant - eller om det er del av en propaganda som først og fremst har til hensikt å fremme salg av produkter.

\section{Litteratur}

1. Elliott C. The deadly corruption of clinical trials. 2010. www.motherjones.com/ environment/2010/09/dan-markingson-drug-trial-astrazeneca (3.12.2013).

2. McEvoy JP, Lieberman JA, Perkins DO et al. Efficacy and tolerability of olanzapine, quetiapine, and risperidone in the treatment of early psychosis: a randomized, double-blind 52-week comparison. Am J Psychiatry 2007; 164: 1050-60.

3. Investigate the death of Dan Markingson. 2013. http://danmarkingson.wordpress.com. (3.12.2013)

4. World Medical Association. World Medical Association Declaration of Helsinki: ethical principles for medical research involving human subjects. JAMA 2013; 310: $2191-4$ 